FEDERAL RESERVE BANK OF SAN FRANCISCO

WORKING PAPER SERIES

\title{
Quantitative Easing and Japanese Bank Equity Values
}

\author{
Takeshi Kobayashi \\ Chukyo University \\ Mark Spiegel \\ Federal Reserve Bank of San Francisco \\ and \\ Nobuyoshi Yamori \\ Nagoya University
}

July 2006

Working Paper 2006-19

http://www.frbsf.org/publications/economics/papers/2006/wp06-19bk.pdf

The views in this paper are solely the responsibility of the authors and should not be interpreted as reflecting the views of the Federal Reserve Bank of San Francisco or the Board of Governors of the Federal Reserve System. This paper was produced under the auspices for the Center for Pacific Basin Studies within the Economic Research Department of the Federal Reserve Bank of San Francisco. 


\title{
QUANTITATIVE EASING AND JAPANESE BANK EQUITY VALUES
}

\author{
Takeshi Kobayashi $^{\dagger}$ \\ Chukyo University, \\ Mark M. Spiegel* \\ Federal Reserve Bank of San Francisco, \\ and \\ Nobuyoshi Yamori \\ Nagoya University
}

\begin{abstract}
One of the primary motivations offered by the Bank of Japan (BOJ) for its quantitative easing program -- whereby it maintained a current account balance target in excess of required reserves, effectively pegging short-term interest rates at zero -- was to maintain credit extension by the troubled Japanese financial sector. We conduct an event study concerning the anticipated impact of quantitative easing on the Japanese banking sector by examining the impact of the introduction and expansion of the policy on Japanese bank equity values. We find that excess returns of Japanese banks were greater when increases in the BOJ current account balance target were accompanied by "nonstandard" expansionary policies, such as raising the ceiling on BOJ purchases of longterm Japanese government bonds. We also provide cross-sectional evidence that suggests that the market perceived that the quantitative easing program would disproportionately benefit financially weaker Japanese banks.

Keywords: quantitative easing, Bank of Japan, liquidity trap, Japanese banks

JEL Classification nos.: E44, G18, G21

*Corresponding author. Federal Reserve Bank of San Francisco, 101 Market Street, San Francisco, CA, 94105, (415)-974-3241, e-mail: mark.spiegel@sf.frb.org.

${ }^{\dagger}$ Helpful comments were received from Naohiko Baba, Mitsuhiro Fukao, Takeo Hoshi, Takatoshi Ito, Clas Wihlborg, an anonymous referee, and seminar participants at the TRIO conference, University of Tokyo, and at the West Coast Japan Economic Seminar at UC San Diego. The views expressed in this paper are those of the authors and do not necessarily reflect those of the Board of Governors of the Federal Reserve or the Federal Reserve Bank of San Francisco.
\end{abstract}




\section{Introduction}

Convinced that Japan’s economic fundamentals were too severely distressed to be rectified with standard monetary policy measures, on March 19, 2001 the Bank of Japan announced a new policy of “quantitative easing.” Under this policy, the BOJ increased its current account target far beyond the level of commercial bank required reserves. This had the expected impact of reducing the already-low overnight call rate effectively to zero. In addition, the BOJ committed to maintain the policy until the core consumer price index registered “stably” a zero percent or an increase year on year. The policy was in place for almost five years, being formally lifted on March 9, 2006.

In motivating the policy change, the minutes of the policy meeting [BOJ (2001b)] revealed that the Policy Board had paid particular attention to financial market conditions, including the adjustment associated with commercial bank disposal of nonperforming loans and the recent downgrading of the credit of 19 Japanese banks by a major rating agency. In particular, the Policy Board members acknowledged the disjoint between the laudable goal of cleaning Japanese bank balance sheet of problem loans and of the need for accelerated credit creation by Japanese banks.

Given these considerations, a primary goal of the BOJ's quantitative easing program was clearly to provide assistance to the nation's troubled banking sector. In this paper, we examine the market's perception of the ability of quantitative easing policy to achieve such goals by conducting event studies concerning the announcements of the introduction and expansion of the quantitative easing policy.

The ability of quantitative easing to have an impact on the banking sector is controversial. Given that Japanese interest rates were already low at the launch of the 
policy, many authors [e.g. Eggertson and Woodford (2003)] were skeptical that any of the components of the quantitative easing policy could have real effects, even the socalled "non-standard components," such as increasing the ceiling on BOJ purchases of Japanese Government Bonds (JGBs). Subsequent to the implementation of the policy, many characterized the policy as a failure, pointing out that overall Japanese bank lending actually declined over the period in which the policy was implemented and expanded, despite the rapid growth in narrow money that took place [Kimura, et al (2002)]. Still, the fact that banks were under pressure to enhance their financial positions during this period by disposing of problem loans could imply that in the absence of the BOJ's quantitative easing program the rate of credit extension could have fallen at an even more rapid pace. Moreover, there is a possibility that if quantitative easing succeeded in reducing longer-term rates, it could have disproportionately benefited weaker Japanese banks.

The International Monetary Fund [IMF (2003)] recently argued that the quantitative easing policy has been a mixed blessing for the Japanese financial system. On one hand, they acknowledge that low nominal interest rates have had the positive impact of stabilizing the sector and preventing an acceleration of deflation. On the other hand, they argue that low nominal rates increase the difficulty of assessing individual bank and loan conditions, and thereby slow the process of shutting down problem Japanese banks. The IMF also argued that the flattening of the yield curve associated with BOJ purchases of longer-term JGBs has made it more difficult for some banks to achieve profitability, rather than less, as net interest margins have declined. Low nominal 
rates may have also dampened activity in the inter-bank call market, which could further reduce profits for some classes of banks.

There is also evidence that the quantitative easing program has reduced the borrowing advantage enjoyed by financially stronger banks. Baba, et al (2006) demonstrate that the BOJ introduction of quantitative easing policy reduced the variance of certificate of deposit rates across banks, even more than would be expected by the observed decline in the variance of bank credit ratings over their sample period.

While these arguments leave the ultimate impact of quantitative easing on the overall banking sector uncertain, it appears likely, as the IMF has suggested, that the quantitative easing policy disproportionately favors weak Japanese banks over strong ones. Weak banks would disproportionately benefit from the deterioration of regulatory conditions under low nominal rates, and would be likely to suffer less from the reduced inter-bank market activity.

In this paper, we examine the market's expectations concerning the absolute and relative impact of the introduction and extension of the BOJ quantitative easing policy on the Japanese banking sector. Examining the period from the start of quantitative easing in March 2001 to the end of 2004, we identify 10 dates associated with significant announcements concerning changes in the BOJ's quantitative easing policy. We then categorize these events in terms of whether they included only a standard expansion of the quantitative easing policy, identified as an increase in the target for commercial bank current account balances at the BOJ, or whether they also included other enhancements, particularly those that would be expected to have the impact of flattening the Japanese yield curve by reducing longer-term interest rates. 
We then conduct an event study examining the impact of these events on the overall banking portfolio. Our results demonstrate that while raw bank returns usually responded positively to expansion of the quantitative easing program, the overall banking sector experienced significantly greater excess returns when increases in its current account balance targets were accompanied by increases in the ceiling on long-term JGB purchases. Indeed, Japanese banks earned statistically significant positive excess returns on all dates in our study when increases in the current account were accompanied by increases in the ceiling on BOJ purchases of long-term JGBs.

We then turn to a standard cross-sectional event study to examine whether the quantitative easing policy was perceived as disproportionately benefiting weaker Japanese banks. We calculate the excess returns of 87 Japanese banks on the event date marking the introduction of the quantitative easing program, the two event dates on which the overall banking portfolio exhibited statistically significant positive excess returns, and a later event date that coincided with the introduction of Japan's financial revitalization program, which was widely expected to result in an aggressive cleanup of problem Japanese banks. We find one variable, the rate of time deposit growth, to be a robustly negative indicator of bank excess returns at statistically significant confidence levels. These results support the hypothesis that weak banks were expected to disproportionately benefit from the quantitative easing policy, as depositors were removing time deposits from problem Japanese banks at this time due to the anticipated partial reduction in deposit insurance guarantees on these deposits. The exception to these results is the later date, which occurred after the introduction of limited on time deposit 
insurance. In this case, we obtained a statistically-significant negative coefficient on overall deposit growth, rather than growth rates of time deposits alone.

Finally, we also provide some evidence concerning the impact of the introduction of quantitative easing on Japanese industries and firms. At the industry level, we calculate industry excess returns on the event window surrounding the announcement of the quantitative easing policy, and find that positive excess returns were more prevalent among financially troubled Japanese industries. At the firm level, we examine the sensitivity of the excess returns of 49 financially-troubled Japanese firms to the financial positions of their main banks. We find some evidence, as anticipated, that excess returns were larger among firms with weaker main banks. Again, this suggests some anticipation by the market that the quantitative easing policy would disproportionately encourage additional credit extension by problem Japanese banks.

It should be stressed that our event study is certain to underestimate the impact of quantitative easing to some extent, as changes in bank equity values will only reflect the unanticipated component of changes in monetary policy. It is likely that changes in quantitative easing policy were partially anticipated, particularly subsequent to the launch of the program. However, we can still examine which types of changes were treated as positive surprises for bank stock equities. Moreover, we also examine the impact of policy changes in the cross section, which allows us to ascertain the relative impact of policy changes by bank characteristics.

The remainder of this paper is divided into six sections. Section 2 discusses monetary policy by the Bank of Japan under quantitative easing. Section 3 examines the economic arguments concerning whether the quantitative easing policy should or should 
not have real effects. Section 4 examines the empirical evidence concerning the impact of the introduction and expansion of quantitative easing on the overall Japanese banking portfolio and on a cross-section of banks. Section 5 extends the analysis to Japanese industries and firms. Section 6 concludes.

\section{Japanese monetary policy under quantitative easing}

\subsection{The zero interest rate policy}

The Bank of Japan (BOJ) initially attempted to intensify its expansionary policy through standard interest rate reduction channels, by bringing the unsecured call rate close to the zero bound. In September 1998, the BOJ Policy Board reduced the unsecured call rate to 0.25 percent. In February 1999 it reduced rates again to 0.15 percent and announced that further declines would be steadily promoted. These interest rate reductions were termed the "zero interest-rate policy," as the BOJ reduced the call rate close to its boundary level of zero percent. At the same time, the BOJ announced a plan to continue the zero interest-rate policy until "the situation allows for the prospect of the elimination of deflationary concern”.

The BOJ abandoned its zero interest rate policy in August 2000. The Policy Board [BOJ 2000] reported that “... the Bank of Japan feels confident that Japan's economy has reached the stage where deflationary concern has been dispelled, the condition for lifting the zero interest rate policy,” and increased the call rate to 0.25 percent. This reversal was criticized by both the Ministry of Finance (MOF) and the Economic Planning Agency (EPA), who insisted that the policy reversal was premature. The MOF and the EPA both requested a postponement of the vote at the Policy Board until the next 
meeting under Article 19 of the Bank of Japan Law. However, the BOJ rejected the government's request to postpone the vote and approved lifting of the zero interest-rate policy by a 7 to 2 majority.

After six months of continued weakness, the BOJ returned to its zero-interest rate policy by reducing the call rate to 0.15 percent in February 2001. Moreover, the return to the zero interest rate policy was quickly followed by a set of policies chosen at the BOJ Policy Board’s March 19, 2001 meeting, self-described as “... monetary easing as drastic as is unlikely to be taken under ordinary circumstances.”1 The Policy Board noted that Japan's economy had failed to return to a sustainable growth path, and again faced a threat of deterioration, and concluded that more aggressive policy was warranted. ${ }^{2}$

The primary policy innovation was replacing the call rate as the main operating target for money market operations with the outstanding balance of the current accounts at the Bank of Japan. The BOJ initially announced that it intended to increase the current account balance approximately 1 trillion yen to a target of five trillion yen. As this new target level exceeded required reserves, the change was intended to ensure that the Bank provided ample liquidity to the market, as well as reduce the call rate from its 0.15 percent level to a level close to the zero bound. For that reason, targeting the current account balance is also sometimes referred to as "excess reserve targeting” [e.g. Ito and Mishkin (2005)].

\footnotetext{
1 "New Procedures for Money Market Operations and Monetary Easing," Bank of Japan, March 19, 2001.

2 The announcement was after 17:00, which means that the information was not reflected by the market prices on March 19 (Monday). March 20 was a national holiday (Spring Equinox Day), and stock market was closed. Therefore, March 21 (Wednesday) was the first trading day after the announcement.
} 
The Policy Board also made a commitment to maintain its new targeting procedure until the core consumer price index (excluding perishables) registered "stably" a zero percent or positive increase year on year. ${ }^{3}$ Finally, the Bank also announced its intention to increase its rate of long-term government bond purchases from its the current level of 400 billion yen per month to a larger unspecified level, subject to the constraint that its stock of long term "effectively held” government bonds be kept below its outstanding stock of banknotes. ${ }^{4}$

\subsection{The quantitative easing period}

Policy decisions under quantitative easing are displayed in Table 1. The BOJ expanded its current account target ten times between March 2001 and December 2004, when the target reached its final upper target level of Y35 trillion. The increases in current account balances were achieved primarily through monthly purchases of JGBs in open market operations. Monthly purchases grew from 0.4 trillion yen in March 2001 to 1.2 trillion yen in May 2004 [Oda and Ueda (2005)].

The BOJ was generally successful in keeping its monthly current account balances within its announced target ranges, as shown in Figure 1. Still, there were short deviations from the target ranges, most notably in 2005, as reports of insufficient supply hindering the ability of the BOJ to achieve its stated current account target prompted calls

${ }^{3}$ It should be noted that the BOJ did not view this condition as implying that it had adopted a formal inflation targeting procedure, as had been requested by many of its critics, because it had refrained from announcing a desired long-term inflation target.

4 The measured stock of effectively held long-term bond purchases includes adjustments for government bond sales under gensaki repurchase agreements. 
for reducing the current account target range or eliminating the quantitative easing policy and going back to targeting interest rates.

In explaining its decisions to increase its current account balance target, the BOJ usually stressed the need for a liquidity injection into the financial sector. For example, in its explanation of its December 19, 2001 decision, the BOJ noted that "Japan's economy is deteriorating broadly and [is] likely to undergo a severe adjustment phase for the time being. Against this background, looking at the stock market as well as the markets for commercial paper and corporate bonds, price differentials are widening reflecting the credit conditions of each firm. As such, financial institutions and investors are becoming more cautious," and added that "There is concern that, if the deterioration in the financial environment goes too far and adversely affects financing by firms in good condition, it could exert downward pressure on economic activity and prices.” 5

\section{Anticipated Impact of Quantitative Easing}

The subsequently-released minutes of the March 2001 BOJ monetary Policy Board meeting revealed that there was considerable uncertainty among the Policy Board members about the impact of quantitative easing. ${ }^{6}$ It was generally agreed that the policy would quickly push the overall call rate almost all the way to 0 , as it did. ${ }^{7}$ It was also reported that, "A few members were of the opinion that the economic effects of an

\footnotetext{
${ }^{5}$ Bank of Japan (2001a).

${ }^{6}$ Bank of Japan (2001b).

${ }^{7}$ Indeed, because foreign banks were seen as more creditworthy than Japanese banks who themselves enjoyed rates close to 0 percent, the uncollateralized overnight call rate actually dipped modestly into negative territory from time to time [e.g. Nishioka and Baba (2004)].
} 
increase in the outstanding balance of the current accounts at the Bank were uncertain in some respects, but, at the same time, it could not be denied that it might have some effects. Thus, the Bank, in view of the economic situation, should try out the measure as long as no significant harmful effect could be anticipated.” ${ }^{8}$ However, some of the Policy Board members questioned whether quantitative easing would have any impact. One member noted that “... since quantitative targeting would not necessarily reduce the overnight call rate to close to zero percent, the targeting of zero interest rates had a stronger commitment effect.” This skepticism was driven by the operations associated with current account balance targeting. Basically, the BOJ swapped near-zero interestbearing assets (short-term JGBs), for zero-interest bearing assets (claims on deposits at the BOJ). The net impact of such a transaction on bank behavior is therefore unclear.

The potential for quantitative easing, i.e. expanding the current account when the interest rate is already at the zero bound, to have real effects has been examined recently in a number of papers. First, quantitative easing can influence future interest rate expectations [e.g. Svennson (2001) and Eggertson and Woodford (2003)], by increasing the length of time the public expects interest rates to be maintained at near-zero levels. The central bank can also influence public expectations through credible statements about future monetary policy, such as the commitment to maintain zero interest rates until certain economic conditions are achieved.

Second, quantitative easing can alter the composition of the central bank balance sheet [e.g. Bernanke and Reinhart (2004)]. For example, the central bank can push down long-term yields on government securities by purchasing of longer-term assets.

${ }^{8}$ Bank of Japan (2001b). 
Third, quantitative easing can expand the supply of reserves and the money stock [e.g. Bernanke and Reinhart (2004)]. If money is an imperfect substitute for other assets, private investors will push down yields on other assets as they attempt to rebalance their portfolios towards those assets. In addition, if the central bank replaces interest-bearing government debt with non-interest bearing currency, quantitative easing can have an expansionary fiscal impact, as demonstrated by Auerbach and Obstfeld (2003).

Most would consider the potential for "non-standard" expansionary policy at the zero bound, such as purchases of longer-term securities or other non-standard assets, to succeed in having an expansionary impact to be greater than the potential for expansion through increases in the current account target alone [e.g. Orphanides (2004)]. As mentioned above, the Bank of Japan pursued such non-standard policies in a number of dimensions over the course of the quantitative easing era. In particular, the ceiling on purchases of long-term JGBs was increased 4 times, from an initial limit of 400 billion yen to a limit currently of 1.2 trillion yen. In addition, the BOJ increases the maturity limit on bills purchased, and then subsequently renewed the extension.

However, there is even uncertainty about the potential for these non-standard policies to have any tangible impact. For example, purchases of longer-term securities do not affect long-term interest rates in Eggertson and Woodford's (2003) model if they do not change expectations about future interest rate levels. Moreover, Eggertson and Woodford argue that empirical evidence suggests that the effect of changes in the composition of public debt on relative yields is small. ${ }^{9}$ Shirakawa (2002) confirms that

\footnotetext{
${ }^{9}$ Much of the empirical argument against the potential for manipulating the term structure through open market operations is based upon the perceived lack of success of "Operation Twist," launched under the Kennedy Administration in the United States in an effort to flatten the yield curve. However, as Bernanke, et al (2004) point out, the operation was relatively small, leaving the experience
} 
the impact of both increases in quantitative easing and outright purchases of long-term securities have had little impact on long-term Japanese interest rates.

Empirical evidence about the success of the quantitative easing program has been mixed. Using an event study framework, Bernanke et al (2004) fail to find any evidence of an impact of policy statements by the Bank of Japan on expectations of future monetary policy. However, the same authors find that bond yields in Japan during the quantitative easing period were significantly lower than they would have been predicted to be by their estimated term-structure model, suggesting that quantitative easing may have had real effects.

The more central question to our analysis is the anticipated impact of quantitative easing on the financial sector. To understand what the anticipated impact would be on commercial banks, it is useful to begin by considering the question of why commercial banks would be willing to hold such large quantities of current account balances at the BOJ. The current account balances maintained by the BOJ have far exceeded the required reserves faced by Japanese commercial banks, on an order of magnitude of approximately Y 25 trillion.

There are a number of theoretical reasons why banks might be willing to hold excess reserves. First, banks may be interested in securing liquidity, both currently and in the future. Maeda, et al (2005) report that counterparties bid in open market operations more actively when there is greater uncertainty about their liquidity needs. Second, trading in JGBs with the BOJ can achieve desired portfolio rebalancing. The quantity of bidding motivated by portfolio rebalancing needs is greater when financial markets are

questionable as a basis for assessing the potential for manipulating the yield curve through purchases of longer maturity assets. 
particularly volatile. Precautionary demand for liquidity by banks may also allow expansion of current account balances to affect the risk tolerance and willingness to lend of commercial banks. For example, Shirakawa (2002) noted that while demand for excess reserves fell soon after the September 2001 terrorist attack in most developed countries, demand stayed high in Japan due to concerns over corporate bankruptcies and falling equity prices. He notes that the introduction of the Lombard-type lending facility by the BOJ in particular might have had an expansionary impact on bank risk tolerance. Kimura et al (2002) also argue that easing liquidity could have a stabilizing impact on financial markets and perhaps induce a portfolio shift resulting in credit creation.

However, there is still relatively little empirical evidence that would suggest real effects from quantitative easing. Romer (1992) finds that the end of the United States great depression was largely attributable to increases in the money supply, suggesting that policies analogous to quantitative easing played a role in ending that episode. While Oda and Ueda (2005) find some evidence that increases in the BOJ current account balances were associated with greater credibility of the zero interest rate policy, they find no significant impact on bond risk premia at medium and long-term maturities.

Still, the consensus is that the quantitative easing policy failed to increase overall bank lending, as it decreased over the quantitative easing period while the money stock grew at around a 3\% rate [Kimura et al (2002)]. Nevertheless, quantitative easing could have had a disproportionate impact on certain types of banks, particularly weaker Japanese banks. The International Monetary Fund (2003) has argued that by pushing down the yield curve to historic lows, the BOJ disproportionately assisted problem banks and delayed the needed consolidation of the Japanese banking industry. 


\section{Empirical Evidence}

\subsection{Return on overall banking portfolio}

In this section, we examine the impact of changes in the BOJ quantitative easing policy on Japanese bank equity values. We pursue an event study approach, concentrating on the impact of decisions expanding the scope of the BOJ's quantitative easing efforts from the inception of the program in March 2001 through the end of 2004.

We examine both the overall return to the banking sector as well as its excess return according to a standard capital asset pricing model specification. It is possible that bank equity values could respond to increases in the intensity of quantitative easing over and above the response levels of the market as a whole. ${ }^{10}$ If this is the case, we are interested in identifying the components of changes in quantitative easing policy that disproportionately benefited the banking sector. Towards that end, we estimated a simple CAPM specification to evaluate bank excess returns on our event dates

$$
\mathrm{BANK}_{t}=\alpha+\beta R_{m t}+\sum_{e=1}^{10} \gamma_{e} D_{e, t}+\varepsilon_{t}
$$

where $B A N K_{t}$ represents the daily stock return of the TOPIX bank index, $R_{m t}$ represents the market portfolio return for day $t$, proxied by the return on the overall TOPIX index, and $\varepsilon_{i, t}$ is assumed to be an i.i.d. disturbance term. $\gamma_{e}$ represents the sensitivity of the bank portfolio to the BOJ meeting announcement represented by the dummy variable

\footnotetext{
${ }^{10}$ The changes observed on our experiment dates could be attributable to other policy changes, such as BOJ Governor comments, on the dates that the current account target was raised [e.g. Oda and Ueda (2005)]. We proceed under the assumption that the primary event on the studied dates was the BOJ policy change specified in the text.
} 
$D_{e, t}$. This variable takes value one on the event date $t$ and zero otherwise. The event dates correspond to the ten dates identified as changes in BOJ policies in Table 2. Estimation is done using ordinary least squares with White's general heteroskedasticity correction. Our estimation period runs from Jan. 4, 2001 through Dec. 30, 2004, and includes a total of 983 trading days.

We estimate events within a single-day event window. However, the March 19, 2001 monetary policy meeting decision was announced after the close of trading on that day, and the next day was a national holiday. As a result, we evaluate the "one-day" return around that event day as the return on the following Wednesday, March 21 (see Figure 2).

Our initial results are shown in Table 2. First, we note that the raw return on these dates on which the quantitative easing policy was expanded was generally positive. The raw return on the banking index was positive 7 out of the 10 event dates, with an average daily raw return to the TOPIX banking portfolio of $2.7 \%$. However, these dates all corresponded to positive returns for the market index as well, as the overall market responded positively to the extension of the quantitative easing policy. The average TOPIX return on one of these event dates was $1.8 \%$. In addition, the bank portfolio is estimated to be very sensitive to the return on the market portfolio, with a point estimate for $\beta$ equal to $1.218 .^{11}$

\footnotetext{
11 To compare the effects of quantitative easing to more standard monetary policy changes in the neighborhood of zero rates, we examined the return on the TOPIX banking portfolio on 2/15/1999 and $8 / 14 / 2000$, the dates corresponding to the beginning and ending of the first zero interest rate policy period. We obtained very insignificant coefficient estimates of 0.004 and 0.005 respectively on these dates, suggesting that these more standard monetary policy changes were not perceived to have as strong an impact on bank equity values as we obtain in this study for some of our event dates. These
} 
The highest individual event day excess returns, of 2.8 and 2.6 percent respectively, occurred on August 14, 2001 and the change subsequent to the meeting on December 19, 2001. These were both dates where in addition to increasing the target for BOJ current account balances, the ceiling on BOJ purchases of long-term JGBs was also increased. On the two later event dates when the ceiling was raised, February 28, 2002 and October 30, 2002, we also obtained statistically significant positive point estimates for the daily excess returns on the bank portfolio of $0.5 \%$ and $0.8 \%$ respectively. Japanese banks therefore earned statistically significant positive excess returns on all dates when the BOJ raised both the current account balance target and the ceiling on purchases of long-term JGBs.

In contrast, there were five event dates where current account balances were increased but ceilings on long-term JGBs were not increased. On three of these five dates, Japanese banks earned negative excess returns that were statistically significant at at least a five percent confidence level. The average return on these five dates was only $0.1 \%$, far below the average for the ten event dates.

The results suggest that banks disproportionately benefited, i.e. achieved statistically measurable positive excess returns, when in addition to raising its current account balance the BOJ acted to flatten the yield curve, either by raising the limit on purchases of long-term JGBs or by raising the maturity limit on BOJ bills purchased. ${ }^{12}$ Nevertheless, quantitative easing appears to also benefit banks by stimulating the overall

results are available upon request from the authors.

12 A large positive excess return was also earned on October 10, 2003, when in addition to raising the current account target and renewing the higher maturity ceiling on bills purchased the BOJ committed to continue its quantitative easing policy until the CPI registered a $0 \%$ or positive increase year-on-year. 
economy through, for example, a reduction in future expected interest rate levels. This would impact the overall economy, including banks, but may manifest itself as an overall increase in the TOPIX index, rather than a disproportionate return on bank equities. As banks have large market betas, this benefit to banks may manifest itself through an increase in the raw return on the overall bank portfolio rather than an increase in bank excess returns.

It should be reiterated that our results only reflect the impact of the unanticipated component of the change in quantitative easing policy. As a result, we are likely to be underestimating the overall impact of the change in policy. Indeed, for a number of the policy changes we obtained significantly negative excess returns on bank equities. These results are better interpreted as indicating dissatisfaction in the market with the magnitude of the increase in current account balances, or whether or not it was accompanied by increases in the ceiling on long-term JGB purchases, rather than a negative impact of the policy change itself.

\subsection{Robustness Checks}

The above specification assumed that the market beta was constant throughout our sample period. However, it is quite possible that the changes in the underlying financial regime over this volatile period affected bank market betas. In this section, we examine the robustness of our results to including shifts in bank market betas.

First, changes in the intensity of the quantitative easing program could also affect banks' market betas. To ensure that our market beta estimates are not being 
contaminated by the changes in BOJ policy, we allow the bank portfolio market beta to shift on each event date.

Second, there were a number of changes in the regulatory regime that could also affect prevailing bank market betas. We identified three major changes that warrant attention: On April 1, 2002 limits were introduced on deposit insurance levels for time deposits. On September 30, 2002, Heizo Takenaka was appointed head of the Financial Services Agency, a move that was perceived as portending more aggressive regulatory efforts at closing failed Japanese banks and cleaning up the financial system. Finally, on October 30, 2002, the Japanese government adopted the Financial Revitalization Program which set aggressive targets for reducing banks' bad loan ratios. We introduce terms allowing for beta shifts on the first two of these three event dates. ${ }^{13}$ Unfortunately, the third event date also contained a BOJ expansion of its current account balance target, so the impact of the regulatory change can not be isolated from this other event.

In addition to the introduction of shifts in the market beta, we also allow for episodes of foreign exchange intervention to affect bank equity values. We introduce a variable, $F X_{t}$, measured as the value of yen sales on date $t .{ }^{14}$

Specifically, we generalize equation (1) to the following specification:

$$
B A N K_{t}=\alpha+\beta R_{m t}+\sum_{e=1}^{10} \gamma_{e} D_{e}+\sum_{e=1}^{10} \beta_{e}\left(R_{m t} \times D_{e t}\right)+\sum_{r=1}^{2} \beta_{r}\left(R_{m t} \times D_{r t}\right)+\beta_{F X} F X_{t}+\varepsilon_{t}
$$

where equation (2) is the same as equation (1) with the addition of the fourth term allowing for time-varying market betas, the fifth term allowing for beta shifts on the bank

\footnotetext{
${ }^{13}$ Spiegel and Yamori (2003) find that news concerning potential passage of bank regulatory changes in 1998 measurably affected Japanese bank equity values.

${ }^{14}$ Source: Ministry of Finance. All foreign exchange interventions over this period were sales of yen intended to depreciate the Japanese currency.
} 
regulatory change dates, and the sixth term allowing for market effects of yen interventions. $D_{e t}$ and $D_{r t}$ are dummy variables equal to 0 prior to the date of events $e$ and $r$ respectively, and 1 afterwards, while $\beta_{i}(i=e, r)$ represents the coefficient estimate on the beta shift for event date $i$. Finally, $\beta_{F X}$ represents the coefficient estimate on the foreign exchange intervention measure, $F X_{t}$.

Our results are shown in Table 3. None of the market beta shifters is statistically significant, even at a 10\% confidence level, with the exception of the shifter for the April 1, 2002 introduction of caps on insurance of time deposits. In particular, the coefficients on the event dates are quite similar to those with constant $\beta \mathrm{s}$. The coefficient estimate on the foreign exchange intervention variable, $F X_{t}$, is almost exactly zero.

As neither the beta shifts nor the foreign exchange intervention variable were influential, it is not surprising that our results concerning bank excess returns were almost identical to those in Table 2. The two largest event dates are again August 14, 2001 and December 19, 2001, with returns of 3.2\% and 2.6\% respectively. As before, the excess return estimates for event dates where the BOJ only increased the current account balance target were much smaller.

\subsection{Parametric evidence}

We next turn to parametric evidence concerning the impact of the different forms of quantitative easing on the overall banking portfolio. Table 1 groups the various event dates into three dummy variables. CA represents a dummy variable that takes value 1 on all event dates when the BOJ raised its current account balance target. YC represents a dummy variable that takes value 1 on all event dates when the BOJ pursued actions 
associated with flattening the yield curve. We include all increases in the limit on the ceiling on long-term JGB purchases and increases or renewals in increases of maturity limits on bills purchased.

Finally, $L T$ is a dummy variable that takes value 1 on the subset of event dates in $Y C$ that also involved increases in the limit on the ceiling on long-term JGB purchases. The last dummy is almost identical to the second one, and is intended as an additional robustness test. In particular, we are concerned about the extra-normal return experienced by banks on October 10, 2003. As mentioned above, in addition to the increase in the current account target and the limit on long-term JGB purchases, the BOJ announced its conditions for ending its quantitative easing policy, raising its commitment to maintain the policy for some period of time. To the extent that this policy change results in lower expected future short-term rates, it may also be a policy associated with “flattening the yield curve.” Nevertheless, we isolate the events where limits on the ceiling on long-term JGB purchases were raised to isolate the impact of this type of policy change. As above, we estimate the bank portfolio market beta jointly with our test of the significance of the event dates. We first test the significance of the increases in the current account targets alone with the simple specification ${ }^{15}$

$$
B A N K_{t}=\alpha+\beta R_{m t}+\gamma_{C A} C A+\varepsilon_{t}
$$

where our variable of interest is $\gamma_{C A}$.

Our results are shown in Table 4. We obtain a similar estimate for our market beta

\footnotetext{
${ }^{15}$ Since none of the coefficient estimates in Table 3 for the market beta shifters was significant at even a $10 \%$ confidence level, we maintain the assumption that the market beta coefficient was constant throughout our sample period.
} 
of around 1.2. Increases in the current account balance alone also appear to be priced positively with a coefficient estimate of close to 0.9 percent, although our coefficient estimate is statistically insignificant.

However, many of these event dates included other changes in BOJ policy, particularly changes associated with flattening the yield curve through easing the restrictions on BOJ purchases of long-term JGB bonds or increasing the maturity limit on bills purchased by the BOJ. To investigate whether excess returns on the banking portfolio were attributable to current account target increases or these yield curve flattening events, we add the $Y C$ and $L T$ dummies in models 2 and 3.

The addition of these dummy variables markedly reduces the coefficient estimate on the current account dummy. This variable now enters insignificantly different from zero. In contrast, both of the yield curve dummies are economically and statistically significant. The overall yield curve dummy ( $Y C$ ) enters significantly with a coefficient estimate of $1.7 \%$ at a $5 \%$ confidence level. The dummy for only increases in the limit on long-term JGB purchases has a modestly smaller point estimate at $1.5 \%$ and is also statistically significant at a 5\% confidence level.

The parametric results therefore support our results from overall bank portfolio returns on individual event dates. While banks generally did better on days when the BOJ raised its current account balance target, it appears that they did measurably better when these current account target increases were accompanied by other policy changes that could have the impact of flattening the yield curve. 


\subsection{Cross-Sectional Evidence}

In this section, we examine the impact of changes on BOJ quantitative easing policy on a cross-section of 87 Japanese banks. As mentioned above, there has been speculation that the BOJ quantitative easing policy disproportionately benefited weaker Japanese banks. We therefore examine important policy event dates to examine whether or not this is the case. In particular, we conduct cross sectional analysis on the March 19, 2001 event date, corresponding to the introduction of the quantitative easing program, as well as the two event dates that yielded statistically significant excess returns to the overall banking index, August 14, 2001 and December 19, 2001. Recall that both of these latter event dates included increases in the ceiling on BOJ purchases of long-term JGBs in addition to increases in the BOJ current account target. Finally, we also examine the impact of BOJ policy changes on October 30, 2002, a date that also corresponded to the introduction of Japan's financial revitalization program.

As discussed above, changes in bank equity values on our event dates would only affect the surprise component of the policy change, and not its expected component. To measure the magnitude of the surprise component in the policy changes, we examined the change in interest rates on the event dates considered in our cross-sectional tests (Table 5). It can be seen that the largest change came in on the March 19, 2001 event, the introduction of the quantitative easing program, where we saw declines in yields at the one-night, 5-year and 10-year maturities of 5, 6, and 8 basis points respectively. It should be stressed that due to the low prevailing nominal rates at the time, these decreases were substantial in percentage terms. For example, the overnight rate declined by $54 \%$ in a single event day. 
The declines on the other event dates were not nearly as dramatic. Of course, overnight rates were already near zero, so we would not expect much response at this maturity. However, on the August 14, 2001 event date we only saw 2 and 0.5 basis point declines in the yields on the 5 and 10 year JGBs respectively. Similarly, we saw a marginal increase in the 5-year yield and actually saw a 3 basis point increase in the 10year yield on our December 19, 2001 event date.

The changes observed in the yield curves, as measured by the differences in the yields on 10 and 5-year Japanese government bonds, were similar. There was a relatively substantial decline in the steepness of the yield curve on the March 19, 2001 introduction of the quantitative easing program, with the difference between the two yields declining by three basis points, but on the subsequent two event dates, the yield curve actually steepened modestly. Given the concentration on the policy concerning the ceiling of purchases of long-term JGBs at the BOJ, it seems surprising that these policy changes affected bank equity values as a group but not prevailing long-term interest rates. ${ }^{16}$ We again evaluate the excess return on bank $i$ on date $t$ in terms of a capital asset pricing model

$$
A R_{i t}=R_{i t}-\alpha_{i}-\beta_{i} R_{m t}
$$

where $A R_{i t}$ is the estimated excess return of bank $i$ on date $t$ and $\alpha_{i}$ and $\beta_{i}$ are estimated market model parameters, and $R_{m t}$ is again the rate of return of the market portfolio on day $t$, proxied by the return on the TOPIX index. We estimate the market

\footnotetext{
${ }^{16}$ Long-term interest rates could have risen and the yield curve could have steepened more than it did in the absence of the policy change, but a formal test of this hypothesis would require a structural model, as in Bernanke, et al (2004), and be beyond the scope of our study.
} 
model parameters over our entire sample. ${ }^{17}$ There were 87 banks that traded continuously over this period, which determined our sample size. All stock price data was obtained from the Toyo Keizai Shinposha stock price data set.

We estimate the standard error of daily abnormal returns on day $t, S_{i}(t)$, is as follows

$$
S_{i t}=\sigma_{i} \sqrt{1+\frac{1}{100}+\frac{\left(R_{m t}-\bar{R}_{m t}\right)^{2}}{\sum_{s=-120}^{-21}\left(R_{s t}-\bar{R}_{m t}\right)^{2}}}
$$

where $\sigma_{i}$ is the residual standard error from our market model estimation and $\bar{R}_{m t}$ is the mean return on the market portfolio during the estimation period.

We next turn to the implications of bank characteristics for observed excess returns. In particular, we concentrate on indicators of firm financial conditions. If the quantitative easing policy was expected to disproportionately favor financially weak firms, we would expect indicators of relatively poor financial conditions to obtain a positive coefficient. Individual bank data was obtained from the Japanese Bankers Association Analysis of financial statements of all banks, individual bank financial reports, and the Deposit Insurance Corporation of Japan (DICJ) web site. ${ }^{18}$

We include seven indicators of individual bank financial conditions in our specifications: First, we include bank Liquidity ratios, measured as the ratio of cash, reserve, and call loans to total bank assets. We also include bank Bad loan ratios,

${ }^{17}$ As a robustness check, we also estimated the market model parameters for the March 19, 2001 event using 100 daily returns beginning 120 trading days before the event day $(t \in[-120,-21])$. These results were very similar to those reported, and are available from the authors on request.

18 The DICJ web site address is http://www.dic.go.jp/english/index.html. 
measured as the ratio of non-performing loans requiring risk management, as defined by the Japanese Banking Law, to net bank assets. We include measures growth in overall and time deposits relative to the previous fiscal year, labeled Deposit growth and Time deposit growth respectively. We include a dummy variable, International operations, which takes value 1 if a bank is engaged in international operations and 0 otherwise. We also include a dummy variable labeled Dividend, which takes value 1 if banks failed to pay the median level of dividends paid by their regulatory class in the previous fiscal year and 0 otherwise. ${ }^{19}$ We include a dummy variable, Public funds, which takes value 1 for banks which have received public funds and value 0 otherwise. Finally, we include a dummy variable Bank Type, which takes value 1 if a bank is a city or trust bank.

Under the hypothesis that the quantitative easing program was expected to disproportionately benefit weaker commercial banks, we would expect a positive coefficient on the Bad loan ratio and Dividend variables, which both indicate financial distress, and a negative coefficient on the liquidity ratio, Deposit growth and Time deposit growth variables.

The Time deposit growth variable, in particular, may be an indicator of financial strength for the events we consider in our cross-section study. In 2001 the Japanese government announced a plan to replace its total deposit insurance guarantees by March 2002 with a partial deposit insurance system, where coverage would be limited to 10 million yen per depositor on time deposits. This reduction in insurance coverage was referred to locally as the "pay-off" policy. The public responded to the announcement by reallocating their savings portfolios towards demand deposits prior to the announced date

19 Median dividend payouts for City and Trust banks was 7 yen a share, while median payouts for regional banks was 5 yen a share. 
of the policy change: Demand deposits increased from 139 trillion yen in March 2000 to 152 trillion yen in March 2001, while time deposits decreased from 282 trillion yen to 278 trillion yen. In addition, while aggregate deposits grew over this period, several notable banks that subsequently failed experienced sharp deposit declines. Spiegel and Yamori (2006) find that time deposit growth was related to financial strength during this period for Japanese regional banks that had adopted market price accounting.

Our expected sign on the International operations and the Public funds variables are unclear. Involvement in International operations usually implies a larger bank with branches abroad, which would tend to be a safer bank. However, during our event period, large banks were known to be heavily dependent on the deferred tax assets in their balance sheets, and therefore were under greater pressure to liquidate their problem loans. Nevertheless, we condition for international operations because involvement in international operations subjects Japanese banks to a higher capital standard.

The expected sign on the Public funds variable is unclear because of the restrictions that accompanied acceptance of public funds. On one hand, an injection of public funds would directly enhance a bank’s balance sheet. However, banks accepting public funds were required to follow the government's "Business Revitalization Plan,” which required large decreases in bank officers and branches, as well as increased lending to small firms. Shimizu (2006) finds that the adverse impact of these regulatory burdens on average outweighed their benefits.

In addition we added a variable for bank size, Scale, measured as the log of total bank assets. It appears likely that several of the variables in our specification already implicitly proxy for bank size, such as International operations and Bank Type, but we 
report our results with and without the additional Scale variable as a robustness check.

The results are shown in Table 6 . We first report our results without the inclusion of the Scale variable. For the March $19^{\text {th }}$ event date, four variables enter significantly at

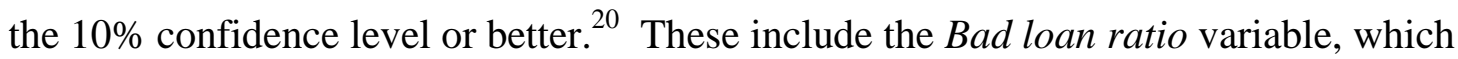
enters significantly at a 5\% confidence level with its expected positive coefficient, and the time deposit growth variable, which also enters at a 5\% confidence level with its expected negative sign. These results suggest that the market expected the quantitative easing program to disproportionately benefit banks in poor financial condition and banks that had been losing, or at least not gaining, time deposits.

The two variables with uncertain expected coefficient signs both enter significantly at a $10 \%$ confidence level. The International operations variable enters negatively, suggesting that banks uninvolved in international operations were expected to benefit more from the quantitative easing policy. This would be in line with the notion that banks with international operations would tend to be larger banks with less financing difficulties holding all else equal. The Public Funds variable also enters negatively, suggesting that banks that received public funds were expected to fare better under quantitative easing.

We also examine cross-section event studies for the two event dates that result in statistically significant positive excess returns on the overall banking portfolio, August 14, 2001 and December 19, 2001. On the August $14^{\text {th }}$ date, two of the variables enter significantly. The time deposit growth variable again enters significantly at a $5 \%$

${ }^{20}$ Of the 87 banks in our sample, 27 exhibited positive excess returns on the March 19 event date at a $10 \%$ confidence level or stronger, while only two had measurably negative excess returns. 
confidence level with its expected negative sign, suggesting that the market expected that quantitative easing would disproportionately benefit banks with difficulties raising deposits. The Dividend variable also entered at a $1 \%$ confidence level with the incorrect negative sign. This would suggest that banks that failed to meet the median dividend payout of their regulatory class would be expected to disproportionately benefit less from the quantitative easing program than other Japanese banks. As only problem banks tend to miss their dividend payments, this result conflicts with the hypothesis that the quantitative easing program was expected to disproportionately benefit weaker Japanese banks.

The Time deposit growth variable also enters significantly with its expected negative sign on our December 19 event date, again at a 5\% confidence level. In addition, the overall deposit growth variable entered significantly positive at a 5\% confidence level. This is not the anticipated sign, but the results for overall deposits may reflect anticipation (which proved to be true) that the removal of deposit insurance on demand deposits would be delayed. ${ }^{21}$

Adding the Scale variable does not appear to qualitatively change our results. The variable itself only enters significantly on the March 19, 2001 event date. The set of variables that enter significantly on the event dates studied are largely invariant to the inclusion of this variable, with the notable exception of the Time deposit growth variable on the March 19 event date, which fails to enter significantly when the Scale variable is included, although it still enters with its expected negative sign.

\footnotetext{
${ }^{21}$ Spiegel and Yamori (2006) fail to find evidence of depositor discipline in terms of overall deposit growth.
} 
Finally, we also report results for the October 30, 2002 event date. This date is distinct from the others in two aspects: First, it occurred after the March 2001 introduction of limits to deposit insurance on time deposits, so depositors may have already made their deposit reallocations in anticipation of the introduction of ceilings on deposit insurance. Second, the introduction of Japan’s financial revitalization program was also announced on this date. It was widely perceived that this program would require banks to aggressively address their problem loans, a burden that would disproportionately fall on weaker Japanese banks.

Our results are notably different from the other event dates. First, time deposit growth rates no longer enter significantly, while overall deposit growth rates do with a statistically significant negative coefficient. This result would be consistent with quantitative easing having disproportionately beneficial impacts on weaker Japanese banks if depositors were now moving all deposits out of weaker Japanese banks. Still, it seems surprising that we obtained negative coefficients on deposit growth at all, given the potential that the regulatory reforms also introduced on that date would broadly be perceived as negative news for weaker Japanese banks. Still, the reforms were primarily applied to larger banks, while our sample is predominantly regional banks that were largely unaffected by the reforms.

\section{Impact on industries and firms}

Given that our results suggest that quantitative easing disproportionately benefited weaker banks, it seems natural to ask whether weaker firms also disproportionately benefited from the policy. To investigate this question, we next turn to the impact on 
Japanese equities sorted by industry. We use indices of weighted equity values for 32 industries calculated by the Tokyo Stock Exchange. As above we estimate individual industry excess returns according to the CAPM model in equation (3).

Our results are shown in Table 7. Ten of the industries enter significantly positively at a least a $10 \%$ confidence level, including Pharmaceuticals, Electric Power and Gas, Retail Trade, Air Transportation, Land Transportation, Foods, Metal Products, Real Estate, Fishery, Agriculture and Forestry, and Construction. A number of these industries experienced significant financial difficulties during this period, particularly the construction industry, the real estate industry and the retail trade industry. In addition, a number of the other industries that experienced significantly positive excess returns on our event date were highly indebted, including the Electric Power and Gas, Land Transportation, and Air Transportation industries. Both of these conditions suggest conditions of financial distress, and their positive excess returns on our event date suggest that the quantitative easing policy was indeed expected to disproportionately benefit weaker industries. In contrast, there were four industries that experienced significantly negative excess returns on our event date. These include Non-ferrous metals, Electric Appliances, Precision Instruments, and Securities. These industries do not seem to be notably troubled, with the possible exception of the securities industry.

Finally, we also examined the performance of individual firms on our event date. As in the case of Japanese industry, we would expect that problem firms would disproportionately benefit from quantitative easing, as they would be more sensitive to any resulting changes in longer-term interest rates. However, another goal of the quantitative easing program was to encourage additional lending by Japanese banks. As 
Japanese firms are still sensitive to the credit policies of their main banks, we would expect the impact of quantitative easing to have the greatest impact on weak firms with weak main banks, and the weakest impact on strong firms with strong main banks.

To test this hypothesis, we concentrate on a sample of financially-troubled firms, identified as firms receiving speculative-grade credit ratings below Baa- by Moody’s investment service. We also limited our sample to firms that had positive trade volume for all of the days in our sample window and had a solvent main bank. In particular, we exclude firms that had government-affiliated main banks, such as the Development Bank of Japan, agricultural main banks, such as the Norinchukin Bank, and insolvent main banks, such as Nippon Credit Bank. ${ }^{22}$

We regress the cumulative abnormal returns of these firms over the 3/21-3/22 2001 event period on the financial characteristics of their main banks. Our specification includes Capital, the main bank capital-asset ratio, Liquidity, a measure of the liquidity position of the main bank, measured as the ratio of cash plus reserves plus call loan balances to total assets, and Bad Loan, measured as the ratio of bad loans to bank net assets.

Our results are shown in Table 8. It can be seen that only one of the variables, Capital, enters with statistical significance (at a 10\%) confidence level. This result provides weak evidence that the financial strength of a firm main bank influenced its sensitivity to the announcement of the quantitative easing program, with financially weak firms with weak main banks experiencing the strongest relative returns, as predicted. Still, the poor results for the Liquidity and Bad Loan variables suggest either that the

\footnotetext{
${ }^{22}$ We identify the main bank of each firm using the Nikkei Kaisha Joho (Nikkei Company Report) published by Nihon Keizai Shinbunsha. The book lists banks with relationships with each firm, and we identify the main bank of each firm as a bank shown at the top of the list.
} 
dependence of the problem firms on their main banks is limited, or that the Capital variable is a sufficient statistic for main bank financial strength.

\section{Conclusion}

This paper examines the impact of the introduction and expansion of the BOJ quantitative easing program on the equity values of Japanese banks. We find that a weighted portfolio of the overall banking system experienced statistically significant positive returns primarily when increases in the BOJ current account target were accompanied by so-called non-standard monetary policies aimed at flattening the yield curve, such as increases in the ceilings on BOJ purchases of JGBs. Indeed, in our base specification Japanese banks earned statistically significant positive excess returns on all dates when increases in the current account were accompanied by increases in the ceiling on BOJ purchases of long-term JGBs, while they earned negative excess returns on four

of the five event dates when increases in the current account target were not accompanied by increases in these ceilings.

We also examine cross-sectional evidence concerning the determinants of abnormal returns to Japanese bank equities on several important event dates associated with the introduction and expansion of the quantitative easing policy. Our results support the contention that the quantitative easing policy was expected to disproportionately benefit weak Japanese banks. We also find that the policy was expected to benefit weak Japanese industries and firms with financially troubled main banks disproportionately.

Our results therefore tend to support the notion that quantitative easing may have had the benign impact of strengthening Japanese financial conditions, particularly with 
respect to weaker Japanese banks. However, as the IMF report cited above discussed, this may not have been an unmixed blessing. If quantitative easing disproportionately benefited the weakest Japanese banks and industries, the policy may have delayed needed restructuring by keeping these weak entities afloat. 


\section{Figure 1}

\section{Current Account Target and Actual Deposits}

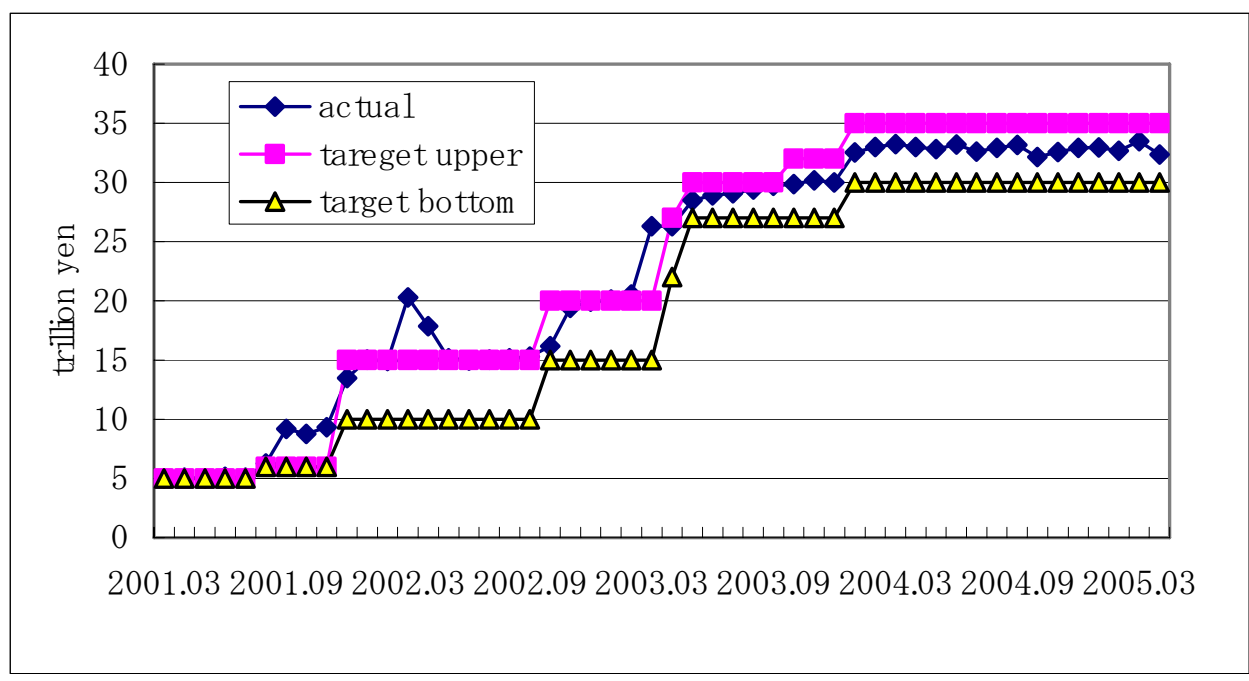

(Note) Figure shows monthly average balance of BOJ current deposits as well as upper and lower target ranges. Prepared by the authors based on Bank of Japan data. 


\section{Figure 2}

\section{TOPIX and Bank Index around the event day (March 212001}

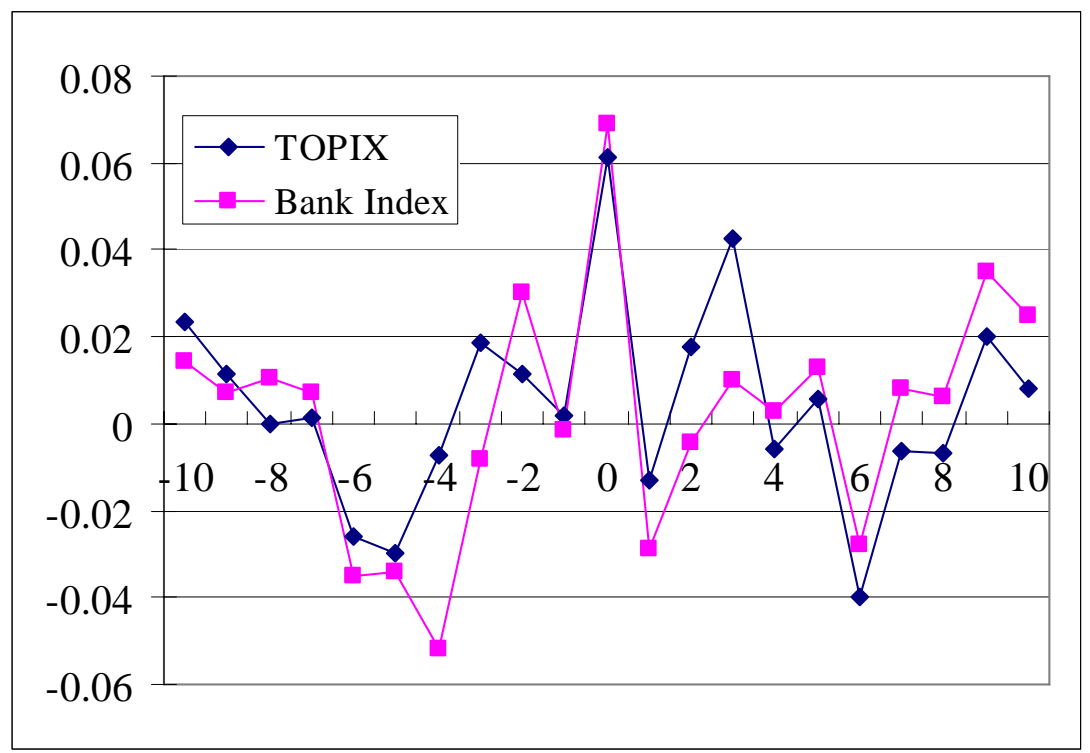

Note: Due to the national holiday following the BOJ announcement of the quantitative easing policy on March 19, date 0 for this event is set at March 21. 
Table 1

BOJ Monetary Policy Decisions Under Quantitative Easing Policy

(3/19/01-12/17/04)

\begin{tabular}{|c|c|c|c|c|c|c|}
\hline Date & $\begin{array}{l}\text { Current Account } \\
\text { Balances }\end{array}$ & $\begin{array}{l}\text { Long-term JGB } \\
\text { monthly purchase } \\
\text { target }\end{array}$ & Other Changes & CA & YC & $\mathrm{LT}$ \\
\hline $3 / 19 / 01$ & $\begin{array}{l}\text { Increased Y } 1 \text { trillion } \\
\text { to Y } 5 \text { trillion }\end{array}$ & $\begin{array}{l}\text { Allowed to exceed Y } \\
400 \text { billion limit }\end{array}$ & & 1 & 0 & 0 \\
\hline $8 / 14 / 01$ & $\begin{array}{l}\text { Increased Y } 1 \text { trillion } \\
\text { to Y } 6 \text { trillion }\end{array}$ & $\begin{array}{l}\text { Increased Y } 200 \\
\text { billion to Y } 600 \\
\text { billion }\end{array}$ & & 1 & 1 & 1 \\
\hline $9 / 18 / 01$ & $\begin{array}{l}\text { Allowed to exceed Y } 6 \\
\text { trillion limit }\end{array}$ & & $\begin{array}{l}\text { Discount rate reduced from } \\
0.15 \text { to } 0.10 \text {, and } \\
\text { maximum discount loan } \\
\text { term extended to } 10 \\
\text { business days }\end{array}$ & 0 & 0 & 0 \\
\hline $12 / 19 / 01$ & $\begin{array}{l}\text { Increased Y 4-9 trillion } \\
\text { to Y } 10-15 \text { trillion }\end{array}$ & $\begin{array}{l}\text { Increased Y } 200 \\
\text { billion to Y } 800 \\
\text { billion }\end{array}$ & $\begin{array}{l}\text { Broadened set of } \\
\text { acceptable commercial } \\
\text { paper and asset-backed } \\
\text { securities }\end{array}$ & 1 & 1 & 1 \\
\hline $2 / 28 / 02$ & $\begin{array}{l}\text { Allowed to exceed Y } \\
10-15 \text { trillion target }\end{array}$ & $\begin{array}{l}\text { Increased Y } 200 \\
\text { billion to Y } 1 \text { trillion }\end{array}$ & $\begin{array}{l}\text { Suspended limit on } \\
\text { number of business days } \\
\text { for discount borrowing }\end{array}$ & 0 & 1 & 1 \\
\hline $10 / 30 / 02$ & $\begin{array}{l}\text { Increased Y } 5 \text { trillion } \\
\text { to Y } 15-20 \text { trillion }\end{array}$ & $\begin{array}{l}\text { Increased Y } 200 \\
\text { billion to Y } 1.2 \\
\text { trillion; maturity } \\
\text { limit for bills } \\
\text { purchased increased } \\
\text { to } 1 \text { year }\end{array}$ & & 1 & 1 & 1 \\
\hline $3 / 25 / 03$ & $\begin{array}{l}\text { Increased Y } 2 \text { trillion } \\
\text { to Y } 17-22 \text { trillion } \\
\text { (After 4/1/03) }\end{array}$ & & & 0 & 0 & 0 \\
\hline $4 / 30 / 03$ & $\begin{array}{l}\text { Increased Y } 5 \text { trillion } \\
\text { to Y } 22-27 \text { trillion }\end{array}$ & & & 1 & 0 & 0 \\
\hline $5 / 20 / 03$ & $\begin{array}{l}\text { Increased Y 3-5 trillion } \\
\text { to Y 27-30 trillion }\end{array}$ & & & 1 & 0 & 0 \\
\hline $10 / 10 / 03$ & $\begin{array}{l}\text { Increased Y } 2 \text { trillion } \\
\text { to Y 27-32 trillion }\end{array}$ & $\begin{array}{l}\text { Renewed extension } \\
\text { of maturity limit for } \\
\text { bills purchased }\end{array}$ & $\begin{array}{l}\text { Commited to maintaining } \\
\text { quantitative easing until } \\
\text { CPI registers a } 0 \% \text { or } \\
\text { increase year on year }\end{array}$ & 1 & 1 & 0 \\
\hline $1 / 20 / 04$ & $\begin{array}{l}\text { Increased Y } 3 \text { trillion } \\
\text { to Y } 30-35 \text { trillion }\end{array}$ & & & 1 & 0 & 0 \\
\hline
\end{tabular}

Note: Table lists BOJ Policy Board meetings at which current account targets were changed.

Unlisted meetings included no changes. Note that we also eliminate BOJ decision on March 25, 2003 to increase the current account target by two trillion yen to accommodate the new regulation that required the Japan Post to begin holding about 2 trillion yen in its current deposits at Bank of Japan on April 1, 2003. Definitions of dummy variables CA, YC, and LT are contained in the text. 
Table 2

Bank Index Returns on Individual Quantitative Easing Event Dates

\begin{tabular}{|c|l|l|l|c|c|c|}
\hline Event Date & CA & YC & LT & $\begin{array}{c}\text { Raw return on } \\
\text { BANK }_{t}\end{array}$ & $\begin{array}{c}\text { TOPIX } \\
\text { return }\end{array}$ & $\begin{array}{c}\text { Excess Return } \\
\text { on BANK }\end{array}$ \\
\hline Mar. 21, 2001 & 1 & 0 & 0 & 0.069 & 0.061 & $\begin{array}{c}-0.006^{* *} \\
(0.002)\end{array}$ \\
\hline Aug. 14, 2001 & 1 & 1 & 1 & 0.061 & 0.027 & $\begin{array}{c}0.028^{* * *} \\
(0.001)\end{array}$ \\
\hline Sep. 18, 2001 & 0 & 0 & 0 & -0.001 & 0.017 & $\begin{array}{c}-0.021^{* * *} \\
(0.001)\end{array}$ \\
\hline Dec. 19, 2001 & 1 & 1 & 1 & 0.031 & 0.004 & $\begin{array}{c}0.026^{* * *} \\
(0.000)\end{array}$ \\
\hline Feb. 28, 2002 & 0 & 1 & 1 & 0.013 & 0.007 & $\begin{array}{c}0.005^{* * *} \\
(0.001)\end{array}$ \\
\hline Oct. 30, 2002 & 1 & 1 & 1 & 0.019 & 0.009 & $\begin{array}{c}0.008^{* * *} \\
(0.001)\end{array}$ \\
\hline Apr. 30, 2003 & 1 & 0 & 0 & 0.051 & 0.030 & $\begin{array}{c}0.015^{* * *} \\
(0.001)\end{array}$ \\
\hline May. 20, 2003 & 1 & 0 & 0 & -0.003 & 0.005 & $\begin{array}{c}-0.008^{* * *} \\
(0.000)\end{array}$ \\
\hline Oct. 10, 2003 & 1 & 1 & 0 & 0.036 & 0.015 & $\begin{array}{c}0.017^{* * *} \\
(0.013)\end{array}$ \\
\hline Jan. 20, 2004 & 1 & 0 & 0 & -0.009 & 0.004 & $\begin{array}{c}-0.013^{* * *} \\
(0.013)\end{array}$ \\
\hline
\end{tabular}

Note: Estimation by ordinary least squares with White's heteroskedasticity correction. Estimation period runs from January 4, 2001 through December 30, 2004. In estimation of excess return, constant term was estimated to be -0.00 while coefficient on TOPIX was estimated to be 1.218 and was significant at $1 \%$ confidence level. Estimated R-squared of regression was $0.599 .{ }^{* *}$ indicates significance at $5 \%$ confidence level. *** indicates significance at $1 \%$ confidence level. 
Table 3

\section{Bank Index Returns on Individual Quantitative Easing Event Dates (with time-varying market betas)}

\begin{tabular}{|c|c|c|c|c|c|c|}
\hline Event Date & CA & YC & $\mathrm{LT}$ & $\begin{array}{c}\text { Raw return on } \\
B A N K_{t}\end{array}$ & $\begin{array}{c}\text { Market } \\
\text { Beta Shift }\end{array}$ & $\begin{array}{c}\text { Excess Return } \\
\text { on } B A N K_{t}\end{array}$ \\
\hline Mar. 21, 2001 & 1 & 0 & 0 & 0.069 & $\begin{array}{l}-0.141 \\
(0.220)\end{array}$ & $\begin{array}{c}0.004 \\
(0.010)\end{array}$ \\
\hline Aug. 14, 2001 & 1 & 1 & 1 & 0.061 & $\begin{array}{c}0.028 \\
(0.189)\end{array}$ & $\begin{array}{c}0.032 * * * \\
(0.003)\end{array}$ \\
\hline Sep. 18, 2001 & 0 & 0 & 0 & -0.001 & $\begin{array}{c}0.047 \\
(0.185) \\
\end{array}$ & $\begin{array}{c}-0.020 * * * \\
(0.002)\end{array}$ \\
\hline Dec. 19,2001 & 1 & 1 & 1 & 0.031 & $\begin{array}{c}0.069 \\
(0.241) \\
\end{array}$ & $\begin{array}{c}0.026 * * * \\
(0.001)\end{array}$ \\
\hline Feb. 28, 2002 & 0 & 1 & 1 & 0.013 & $\begin{array}{c}0.236 \\
(0.234) \\
\end{array}$ & $\begin{array}{c}0.004 * * * \\
(0.001)\end{array}$ \\
\hline Oct. 30,2002 & 1 & 1 & 1 & 0.019 & $\begin{array}{c}0.087 \\
(0.239)\end{array}$ & $\begin{array}{c}0.009 * * * \\
(0.001)\end{array}$ \\
\hline Apr. 30, 2003 & 1 & 0 & 0 & 0.051 & $\begin{array}{c}0.064 \\
(0.349) \\
\end{array}$ & $\begin{array}{c}0.014 \\
(0.010) \\
\end{array}$ \\
\hline May. 20, 2003 & 1 & 0 & 0 & -0.003 & $\begin{array}{c}-0.071 \\
(0.361)\end{array}$ & $\begin{array}{c}-0.008 * * * \\
(0.001)\end{array}$ \\
\hline Oct. 10,2003 & 1 & 1 & 0 & 0.036 & $\begin{array}{c}0.282 \\
(0.186)\end{array}$ & $\begin{array}{c}0.013 * * * \\
(0.002)\end{array}$ \\
\hline Jan. 20, 2004 & 1 & 0 & 0 & -0.009 & $\begin{array}{c}-0.086 \\
(-0.132) \\
\end{array}$ & $\begin{array}{c}-0.013^{* * *} \\
(0.001)\end{array}$ \\
\hline \multicolumn{5}{|c|}{ Foreign Exchange Interventions } & & $\begin{array}{c}0.000 \\
(0.000)\end{array}$ \\
\hline \multicolumn{7}{|c|}{ Other Market Beta Shifts } \\
\hline April 1, 2002 & \multicolumn{4}{|c|}{$\begin{array}{c}\text { Introduction of Cap on Time } \\
\text { Deposit Insurance }\end{array}$} & $\begin{array}{l}-0.271^{*} \\
(0.158)\end{array}$ & \\
\hline Sep. 30, 2002 & \multicolumn{4}{|c|}{$\begin{array}{l}\text { Takenaka Appointment to } \\
\text { Financial Services Agency }\end{array}$} & $\begin{array}{l}-0.086 \\
(0.235)\end{array}$ & \\
\hline
\end{tabular}

Note: Estimation by ordinary least squares with White's heteroskedasticity correction. Estimation period runs from January 4, 2001 through December 30, 2004. In estimation of excess return, constant term was estimated to be -0.000 while permanent coefficient on TOPIX was estimated to be 1.207 and was significant at $1 \%$ confidence level. TOPIX returns on event dates are shown in Table 2. Foreign exchange Intervention reflects dollar value of yen assets sold in FX interventions on event date. Market beta shift estimates show coefficient for dummy variable that equals one on and after stated event date, and 0 on earlier dates. See text for details. “Other market beta shifts” reflect changes to financial regulatory regime during sample period. Estimated R-squared of regression was 0.605 . ** indicates significance at 5\% confidence level. *** indicates significance at $1 \%$ confidence level. 


\section{Table 4}

\section{Returns on Banking Index by Event Date Categories}

\section{Dependent variable: Raw return on $B A N K_{t}$}

\begin{tabular}{|c|c|c|c|}
\hline Variable & Model 1 & Model 2 & Model 3 \\
\hline Constant & $\begin{array}{l}-0.000 \\
(0.000)\end{array}$ & $\begin{array}{l}-0.000 \\
(0.000)\end{array}$ & $\begin{array}{l}-0.000 \\
(0.000)\end{array}$ \\
\hline TOPIX & $\begin{array}{l}1.216 * * * \\
(0.037)\end{array}$ & $\begin{array}{l}1.217 * * * \\
(0.037)\end{array}$ & $\begin{array}{l}1.217^{* * *} \\
(0.037)\end{array}$ \\
\hline Increases in current account Balance & $\begin{array}{l}0.009 \\
(0.006)\end{array}$ & $\begin{array}{l}0.000 \\
(0.006)\end{array}$ & $\begin{array}{l}0.003 \\
(0.006)\end{array}$ \\
\hline $\begin{array}{l}\text { Increases in ceiling on long-term JGB } \\
\text { purchases or maturity limit on bills purchased }\end{array}$ & & $\begin{array}{l}0.017 * * \\
(0.007)\end{array}$ & \\
\hline $\begin{array}{l}\text { Increases in ceiling on long-term JGB } \\
\text { purchases }\end{array}$ & & & $\begin{array}{l}0.015^{* *} \\
(0.007)\end{array}$ \\
\hline \# of observations & 983 & 983 & 983 \\
\hline R-squared & 0.594 & 0.596 & 0.596 \\
\hline
\end{tabular}


Table 5

Interest Rate Effects of Changes in Current Account Target

\begin{tabular}{|c|c|c|c|}
\hline Event Date & $3 / 19 / 01$ & $8 / 14 / 01$ & $12 / 19 / 01$ \\
\hline & & & \\
\hline Overnight Call Rate & & & \\
\hline Pre-event & 0.13 & 0.01 & 0.002 \\
\hline Post-event & 0.06 & 0.01 & 0.002 \\
\hline 5-Year JGB & & & \\
\hline Pre-event & & & 0.500 \\
\hline Post-event & 0.483 & 0.416 & \\
\hline & 0.428 & 0.393 & 0.500 \\
\hline 10-Year JGB & & & \\
\hline Pre-event & 1.135 & 1.300 & 1.325 \\
\hline Post-event & 1.050 & 1.295 & 1.355 \\
\hline & & & \\
\hline 10-year minus 5-year & & & 0.825 \\
\hline Pre-event & 0.652 & 0.884 & \\
\hline Post-event & 0.622 & 0.902 & 0.851 \\
\hline & & & 990.5 \\
\hline TOPIX Futures Rate & & & \\
\hline Pre-event & 1180.5 & 1167 & \\
\hline Post-event & 1280 & 1202 & 995 \\
\hline & & & \\
\hline
\end{tabular}

Note: Interest rates in table include uncollateralized overnight call rate, over-the-counter yields for five year Japanese government bond, and yield on newly-issued 10-year Japanese government bond. TOPIX futures are on 3-month-ahead contracts. Event is measured as one day window. 


\section{Table 6}

\section{Cross-Sectional Results}

\begin{tabular}{|c|c|c|c|c|c|c|c|c|}
\hline \multirow{2}{*}{$\begin{array}{l}\text { Event Date } \\
\text { Liquidity } \\
\text { ratio }\end{array}$} & \multirow{2}{*}{\multicolumn{2}{|c|}{$\begin{array}{l}3 / 19 / 01 \\
\\
0.025 \\
(0.086)\end{array}$}} & \multicolumn{2}{|c|}{$8 / 14 / 01$} & \multicolumn{2}{|c|}{$12 / 19 / 01$} & \multicolumn{2}{|c|}{$10 / 30 / 02$} \\
\hline & & & $\begin{array}{l}0.018 \\
(0.041)\end{array}$ & $\begin{array}{l}0.017 \\
(0.041)\end{array}$ & $\begin{array}{l}0.038 \\
(0.149)\end{array}$ & $\begin{array}{l}0.042 \\
(0.149)\end{array}$ & $\begin{array}{l}-0.096 \\
(0.069)\end{array}$ & $\begin{array}{l}-0.093 \\
(0.069)\end{array}$ \\
\hline $\begin{array}{l}\text { Bad loan } \\
\text { ratio }\end{array}$ & $\begin{array}{l}0.001^{* *} \\
(0.006)\end{array}$ & $\begin{array}{l}0.001^{* *} \\
(0.001)\end{array}$ & $\begin{array}{l}0.000 \\
(0.000)\end{array}$ & $\begin{array}{l}0.000 \\
(0.000)\end{array}$ & $\begin{array}{l}-0.001 \\
(0.001)\end{array}$ & $\begin{array}{l}-0.000 \\
(0.001)\end{array}$ & $\begin{array}{l}-0.002 \\
(0.004)\end{array}$ & $\begin{array}{l}-0.002 \\
(0.004)\end{array}$ \\
\hline $\begin{array}{l}\text { Deposit } \\
\text { growth }\end{array}$ & $\begin{array}{l}0.198 \\
(0.165)\end{array}$ & $\begin{array}{l}0.050 \\
(0.190)\end{array}$ & $\begin{array}{l}0.080 \\
(0.084)\end{array}$ & $\begin{array}{l}0.097 \\
(0.095)\end{array}$ & $\begin{array}{l}0.804 * * \\
(0.320)\end{array}$ & $\begin{array}{l}0.662 * \\
(0.368)\end{array}$ & $\begin{array}{l}-0.156^{* *} \\
(0.067)\end{array}$ & $\begin{array}{l}-0.211 * * * \\
(0.079)\end{array}$ \\
\hline $\begin{array}{l}\text { Time deposit } \\
\text { growth }\end{array}$ & $\begin{array}{l}-0.245^{* *} \\
(0.123)\end{array}$ & $\begin{array}{l}-0.136 \\
(0.141)\end{array}$ & $\begin{array}{l}-0.152^{* *} \\
(0.065)\end{array}$ & $\begin{array}{l}-0.166^{* *} \\
(0.073)\end{array}$ & $\begin{array}{l}-0.663^{* *} \\
(0.263)\end{array}$ & $\begin{array}{l}-0.542^{*} \\
(0.305)\end{array}$ & $\begin{array}{l}-0.033 \\
(0.044)\end{array}$ & $\begin{array}{l}0.004 \\
(0.052)\end{array}$ \\
\hline $\begin{array}{l}\text { International } \\
\text { operations }\end{array}$ & $\begin{array}{l}-0.016^{*} \\
(0.007)\end{array}$ & $\begin{array}{l}-0.024^{* *} \\
(0.010)\end{array}$ & $\begin{array}{l}-0.005 \\
(0.004)\end{array}$ & $\begin{array}{l}0.006 \\
(0.004)\end{array}$ & $\begin{array}{l}0.014 \\
(0.014)\end{array}$ & $\begin{array}{l}0.007 \\
(0.016)\end{array}$ & $\begin{array}{l}-0.006 \\
(0.005)\end{array}$ & $\begin{array}{l}-0.009 \\
(0.006)\end{array}$ \\
\hline Dividend & $\begin{array}{l}-0.002 \\
(0.010)\end{array}$ & $\begin{array}{l}-0.003 \\
(0.010)\end{array}$ & $\begin{array}{l}-0.015 * * * \\
(0.005)\end{array}$ & $\begin{array}{l}-0.015^{* * *} \\
(0.005)\end{array}$ & $\begin{array}{l}0.027 \\
(0.020)\end{array}$ & $\begin{array}{l}0.028 \\
(0.020)\end{array}$ & $\begin{array}{l}-0.006 \\
(0.005)\end{array}$ & $\begin{array}{l}-0.004 \\
(0.006)\end{array}$ \\
\hline Public funds & $\begin{array}{l}-0.016^{*} \\
(0.008)\end{array}$ & $\begin{array}{l}-0.030^{* *} \\
(0.013)\end{array}$ & $\begin{array}{l}-0.008 \\
(0.006)\end{array}$ & $\begin{array}{l}-0.007 \\
(0.006)\end{array}$ & $\begin{array}{l}-0.002 \\
(0.025)\end{array}$ & $\begin{array}{l}-0.007 \\
(0.026)\end{array}$ & $\begin{array}{l}-0.004 \\
(0.006)\end{array}$ & $\begin{array}{l}-0.006 \\
(0.007)\end{array}$ \\
\hline Bank type & $\begin{array}{l}0.015 \\
(0.015)\end{array}$ & $\begin{array}{l}0.006 \\
(0.016)\end{array}$ & $\begin{array}{l}0.053 * * * \\
(0.008)\end{array}$ & $\begin{array}{l}0.054^{* * *} \\
(0.009)\end{array}$ & $\begin{array}{l}0.018 \\
(0.032)\end{array}$ & $\begin{array}{l}0.006 \\
(0.035)\end{array}$ & $\begin{array}{l}0.013 \\
(0.009)\end{array}$ & $\begin{array}{l}0.006 \\
(0.011)\end{array}$ \\
\hline Scale & & $\begin{array}{l}0.010^{*} \\
(0.006)\end{array}$ & & $\begin{array}{l}-0.001 \\
(0.003)\end{array}$ & & $\begin{array}{l}0.009 \\
(0.011)\end{array}$ & & $\begin{array}{l}0.004 \\
(0.004)\end{array}$ \\
\hline $\begin{array}{l}\text { \# of } \\
\text { observations }\end{array}$ & 87 & 87 & 84 & 84 & 84 & 84 & 83 & 83 \\
\hline $\mathrm{R}^{2}$ & 0.145 & 0.169 & 0.535 & 0.536 & 0.188 & 0.194 & 0.163 & 0.182 \\
\hline
\end{tabular}

Note: Estimation by ordinary least squares with White's heteroscedasticity correction.

Specifications regress cross section of bank returns on bank characteristics on posted event date. Standard errors are indicated in parentheses. * indicates significance at $10 \%$ confidence level. ** indicates significance at $5 \%$ confidence level while $* * *$ indicates significance at $1 \%$ confidence level. 
Table 7

Industry Excess Returns

3/19/01

\begin{tabular}{|l|r|r|r|}
\hline Industry & AR(0) (\%) & t-value & p-value \\
\hline Fishery, Agriculture and Forestry & $2.12^{*}$ & 1.79 & 0.076 \\
\hline Mining & -2.84 & -0.82 & 0.416 \\
\hline Construction & $2.05^{* *}$ & 2.42 & 0.017 \\
\hline Foods & $3.32^{* * *}$ & 3.85 & 0.000 \\
\hline Textiles and Apparels & 1.09 & 1.04 & 0.302 \\
\hline Pulp and Paper & -2.01 & -1.29 & 0.199 \\
\hline Chemicals & 0.89 & 0.95 & 0.344 \\
\hline Pharmaceutical & $7.34^{* * *}$ & 5.27 & 0.000 \\
\hline Oil and Coal Products & 0.61 & 0.26 & 0.796 \\
\hline Rubber Products & 2.00 & 0.75 & 0.455 \\
\hline Glass and Ceramics Products & 0.14 & 0.11 & 0.915 \\
\hline Iron and Steel & -0.66 & -0.50 & 0.621 \\
\hline Nonferrous Metals & $-4.63^{* *}$ & -2.01 & 0.047 \\
\hline Metal Products & $2.99^{* * *}$ & 2.96 & 0.004 \\
\hline Machinery & -1.50 & -1.74 & 0.085 \\
\hline Electric Appliances & $-3.11^{* * *}$ & -2.95 & 0.004 \\
\hline Transportation Equipment & 1.42 & 1.22 & 0.227 \\
\hline Precision Instruments & $-6.09^{* * *}$ & -4.37 & 0.000 \\
\hline Other Products & -1.69 & -1.24 & 0.219 \\
\hline Electric Power and Gas & $5.01^{* * *}$ & 4.37 & 0.000 \\
\hline Land Transportation & $4.11^{* * *}$ & 4.08 & 0.000 \\
\hline Marine Transportation & 0.04 & 0.02 & 0.982 \\
\hline Air Transportation & $4.25^{*}$ & 1.91 & 0.059 \\
\hline Warehousing and Harbor Services & 1.04 & 0.85 & 0.398 \\
\hline Communication & -3.28 & -1.59 & 0.115 \\
\hline Wholesale Trade & -1.57 & -1.26 & 0.211 \\
\hline Retail Trade & $4.92^{* * *}$ & 3.40 & 0.001 \\
\hline Securities & $-3.71^{* *}$ & -2.04 & 0.044 \\
\hline Insurance & 1.55 & 1.03 & 0.306 \\
\hline Other Financing Business & 1.24 & 0.82 & 0.416 \\
\hline Real Estate & $2.85^{*}$ & 1.79 & 0.077 \\
\hline Services & $-3.59^{* * *}$ & -2.79 & 0.006 \\
\hline
\end{tabular}

Note: Estimated excess returns by industry using CAPM model on March 21, 2001. * indicates significance at $10 \%$ confidence level. $* *$ indicates significance at $5 \%$ confidence level while $* * *$ indicates significance at $1 \%$ confidence level. Reported confidence intervals are relative to standard error of regressions. 


\section{Table 8}

\section{Impact of 3/19/2001 Announcement on Firms by Main Bank}

\section{Characteristics}

Dependent Variable: CAR(3/21-3/22)

\begin{tabular}{|l|l|l|l|}
\hline & Estimate & T-Statistic & P-Value \\
\hline Capital & $-0.03^{*}$ & -1.879 & 0.07 \\
\hline Liquidity & -0.51 & -0.929 & 0.36 \\
\hline Bad Loan & -0.00 & -0.066 & 0.99 \\
\hline \# Obs & 49 & & \\
\hline$R$-squared & 0.08 & & \\
\hline
\end{tabular}

Note: Estimation by ordinary least squares. Regression of cross-section of abnormal returns of 49 problem Japanese firms on event date 3/21/2001-3/22/2001 on financial characteristics of firm main banks. Standard errors are in parentheses. * indicates statistical significance at $10 \%$ confidence level. 


\section{References}

Baba, Naohiko, Motoharu Nakashima, Yosuke Shigemi, and Kazuo Ueda, (2006), “The Bank of Japan's Monetary Policy and Bank Risk Premiums in the Money Market, International Journal of Central Banking, 2(1), 105-135.

Bank of Japan, (2001a), "Change of the Guideline for Money Market Operations," August 11, http://www.boj.or.jp/en/seisaku/05/seisak_f.htm.

Bank of Japan, (2001b), "Minutes of the Monetary Policy Meeting on March 19, 2001, May 1, http://www.boj.or.jp/en/seisaku/05/seisak_f.htm.

Bank of Japan, (2005), “New Procedures for Money Market Operations and Monetary Easing,” March 19, http://www.boj.or.jp/en/seisaku/05/seisak_f.htm.

Bernanke, Ben S., and Vincent R. Reinhart, (2004), “Conducting Monetary Policy at Very Low Short-Term Interest Rates,” American Economic Review, 94(2), 85-90.

Bernanke, Ben S., Vincent R. Reinhart, and Brian P. Sack, (2004), “Monetary Policy Alternatives at the Zero bound: An Empirical Assessment," Brookings Papers on Economic Activity, Issue 2, 1-100.

Eggertson, Gauti and Michael Woodford, (2003), “The Zero Bound on Interest Rates and Optimal Monetary Policy,” Brookings Papers on Economic Activity, 1, 139-211.

International Monetary Fund, “Japan: Financial Stability Assessment and Supplementary Information,” IMF Country Report No. 03/287.

Ito, Takatoshi, and Frederic Mishkin, (2005), “Two Decades of Japanese Monetary Policy and the Deflation Problem, mimeo, May.

Kimura, Takeshi, Hiroshi Kobayashi, Jun Muranaga, and Hiroshi Ugai, “The Effect of the Increase in Monetary Base on Japan's Economy at Zero Interest Rates: An Empirical Analysis,” Bank of Japan IMES Discussion Paper No. 2002-E-22.

Maeda, Eiji, Bunya Fujiwara, Aiko Mineshima, and Ken Taniguchi, (2005), “Japan’s Open Market Operations Under the Quantitative Easing Policy,” Bank of Japan Working Paper Series No. 05-E-3, April.

Nishioka, Shinichi, and Naohiko Baba, (2004), "Negative Interest Rates Under the Quantitative Monetary Easing Policy in Japan,” Bank of Japan Working Paper Series No 04-E-8, Julyl.

Oda, Nobuyuki, and Kazuo Ueda, (2005), “The Effects of the Bank of Japan’s Zero Interest Rate Commitment and Quantitative Monetary Easing on the Yield curve: A Macro-Finance Approach,” Bank of Japan Working Paper Series No 05-E-6, April. 
Orphanides, Athanasios., (2004), "Monetary Policy in Deflation: The Liquidity Trap in Theory and Practice,” North American Journal of Economics and Finance, 15, 101-124.

Romer, Christina, (1992), “What Ended the Great Depression?,” Journal of Economic History, 52(4), 757-784.

Shirakawa, Masaaki, (2002), “One Year Under 'Quantitative Easing,” IMES Discussion Paper Series No. 2002-E-3, April.

Shimizu, Katsutoshi, (2006), "How Can We Effectively Resolve the Financial Crisis?: Empirical Evidence on the Bank Rehabilitation Plan of the Japanese Government," Pacific Basin Finance Journal, 14(2), 119-134.

Spiegel, Mark M. and Nobuyoshi Yamori, (2003), “The Impact of Japan’s Financial Stabilization Laws on Bank Equity Values,” Journal of the Japanese and International Economies, 17, 263-282.

Spiegel, Mark M. and Nobuyoshi Yamori (2006), “ Market Price Accounting and Depositor Discipline: The Case of Japanese Regional Banks,” forthcoming, Journal of Banking and Finance, 2006.

Svensson, Lars E. O., (2001), “The Zero Bound in an Open Economy: A Foolproof Way Of Escaping from a Liquidity Trap,” Monetary and Economic Studies, February, 19, Special Edition, 277-312. 